\title{
Cross-border acquisitions and shareholder wealth: Evidence from the energy and industry in Central and Eastern Europe*
}

\author{
Tomasz P. Bednarczyk, Dirk Schiereck, Hardrik N. Walter**
}

We look at the wealth generated for shareholders of energy assets in Central and Eastern Europe (CEE) by the announcement of cross-border mergers or acquisitions involving a bidder from a Western industrialized country between 1995 and 2005. The impact on both the performance improvements at the firm level as well as on an industry and economic level of foreign ownership of the energy assets in CEE are discussed. The main driver behind the positive effect is the industrial relatedness in acquiring CEE energy assets, while bidder experience and the relative size of the acquired stake do not impact the results significantly.

Wir betrachten die Werteffekte nach Ankündigungen von grenzüberschreitenden Akquisitionen von Unternehmen der Energiewirtschaft in Mittel- und Osteuropa zwischen 1995 und 2005, bei denen jeweils ein westeuropäischer Bieter einbezogen war. Sowohl der Einfluss auf die Unternehmensperformance als auch auf den ausländischen Anteilsbesitz auf Branchenebene wird diskutiert. Als Haupttreiber des positiven Werteffekts kann die Branchenbeziehung ausgemacht werden, während M\&A-Erfahrung und die relative Größe des Kaufobjekts keinen signifikanten Einfluss aufweisen.

Key words: cross-border mergers and acquisitions, capital market integration, corporate control, energy industry

* Manuscript received: 22.07.08, accepted: 13.02 .10 (2 revisions)

** Tomasz P. Bednarczyk, Endowed Chair of Banking and Finance, European Business School, International University Schloß Reichartshausen, Germany. Main research areas: Strategic management and firm value-enhancement through growth and restructuring. Corresponding address: Tomasz.bednarczyk@ebs.edu.

Dirk Schiereck, Chair of Corporate Finance, Department of Business Administration, Economic and Law, Tech University of Darmstadt, Germany. Main research areas: Investment banking, stock market and finance. Corresponding address: schiereck@bwl.tudarmstadt.de.

Hendrik N. Walter, Endowed Chair of Banking and Finance, European Business School, International University Schloß Reichartshausen, Germany. Main research areas: Investment banking and management consulting. Corresponding address: hendrik.walter@ebs.edu. 


\section{Introduction}

To further catch up in economic development, Central and Eastern European (CEE) countries had to overcome the bottleneck of energy supply. The relative need for energy in CEE countries was far higher than that in other OECD countries. In 1996, Hungary, for instance, required four and Poland and the Czech Republic eight times as much primary energy production (measured in relation to GDP) as the reunified German economy. A major part of this need could be contributed to the energy sector itself. The economic incentives for efficiency were problematic. Remote from the market priced fuels and largely subsidized electricity tariffs for consumers were conditions which could not sustain in a market-base energy sector (Pesic/Ürge-Vorsatz 2001).

The search for efficiency gains involved substantial privatization programs. Despite the different privatization procedures applied, the CEE countries agreed on selling large stakes in the state-owned enterprises of the energy sector abroad, since it was seen as a strategic infrastructure for future growth, and domestically there was a lack of required capital sources to restructure the industry and to finance necessary capital expenditures. Consequently, there are a lot of utilities in CEE countries which were to a smaller degree privatized via IPOs (Ahnefeld et al. 2008) and then sold partly to exchange-listed Western companies. Beyond the generation of high transaction prices, the privatizations were also motivated by ecological aspects, which were easier to address for foreign acquirers. The local industry was regarded throughout the entire value chain as the largest polluter in CEE countries (Ürge-Vorsatz et al. 2003). However, the upgrading process of the energy plants and infrastructure to EU standards and the implementation of ecological improvements took time and instant profits were unlikely (Kavanagh 2002).

Although reform of the energy industry is considered to be one of the major contemporary global industrial challenges (Joskow 1998), the restructuring exigency of the energy industry is particularly severe in CEE countries. The privatization of public utilities in developed Western economies started as early as the 1980s and has been followed by an ongoing consolidation through mergers and acquisitions (M\&As). This process has created a few large private oligopolistic (or joint public-private) utility providers with considerable financial strength and geographical reach. When CEE economies started privatization programs in the energy sectors, firms based in Western countries took the opportunity to expand and invest in the newly privatized firms. Prior to the transition in the CEE countries, strict limitations had been imposed on access to foreign (i.e. Western) technology. Lifting the barriers to foreign capital, combined with an expansion in trade links with major industrialized economies, could obviously create the potential for rapid increases in productivity. The energy sector in CEE countries therefore offers, among other benefits, significant growth potential for strategic investors. The market value of utilities 
in the Czech Republic, Poland and Hungary increased by $8 \%$ per year earlier this decade and is expected to grow further at a Compound Annual Growth Rate (CAGR) of 4\%, 5\% and 6\% respectively, while markets in Western Europe are expected to grow (before the global financial crisis) at a CAGR of only $1.5 \%$ (Datamonitor 2005).

Although M\&As have received wide attention for many years now, there have only been a few studies that address the wealth effects of cross-border M\&As, in particular with a European focus (Lowinski et al. 2004; Renze-Westendorf et al. 2009). Moreover, Bohl et al. (2006) state that only very limited research has been conducted on the wealth effects of foreign acquisitions in Central and Eastern Europe. Nevertheless, rapidly transforming markets have attracted increasing attention of transnational corporations due to the investment opportunities they offer (Bekaert/Harvey 2003). A central question in the debate of restructuring transition economies is generally whether the transfer of ownership from domestic to foreign parties through cross-border M\&As results in a creation of surplus value for the target economies. As Uhlenbruck/De Castro (2000) document, the existing evidence is mixed. Hence, this study analyzes the stock price reaction of CEE target firms upon the announcement of an acquisition by a foreign investor. The examination is based on well established event study methodology to calculate capital market reactions around the announcement of M\&A transactions. The main finding shows a remarkably small but significant positive revaluation of the target companies and underlines the importance of a good strategic fit between target and bidder firm.

The remaining sections of this paper are structured as follows. Section 2 reports literature insights on motives of and capital market reactions to general crossindustry M\&A transactions and to specific utility sector evidence. Section 3 develops hypotheses concerning the relationship between stock price reactions of takeover targets and transaction characteristics. Section 4 presents the data sample and applied methodology. Sections 5 and 6 detail the results, and section 7 summarizes the results before drawing final conclusions.

\section{Motives and wealth effects of international M\&A transactions}

The popularity of takeover strategies among energy utilities can be traced back to the extensive deregulation of many national energy supply markets: previously, energy supply was seen as a natural monopoly requiring comprehensive regulation. From the beginning of the 1980s onwards, opinions shifted in America and then later in Europe. Today, only certain sectors of energy supply are still viewed as natural monopolies (Isser 2004; Kiesling 2004). Legislators in many countries introduced elements of market competition. The Directive 96/92/EC and Directive 98/30/EC from 1996 and 1998 respectively established common rules for the internal electricity markets and they provided the foundation for the liberalization of energy supply in the individual European 
Union (EU) member states. In the United States, the structure of power markets changed significantly in the 1990s. Prior to this, it was one of the most tightly regulated industries in the United States. With the passing of the Energy Policy Act in 1992, the electricity wholesale markets were widely deregulated (Energy Information Administration 2003a; Energy Information Administration 2003b).

Despite the high empirical evidence of takeover strategies applied for energy utilities and suppliers, remarkably little well-founded analysis is actually available about the motives. Most of the existing studies either maintain a general perspective without focusing on specific industries, or explicitly exclude the utilities sector. The particular nature of energy supply, i.e. the aforementioned regulation and the resulting market structure, suggests that the drivers of the consolidation process might be very industry specific in this sector.

Takeovers among energy utilities are usually justified by the management as a means of effecting increased efficiency, for example through operative synergies resulting from economies of scale and scope. Revenue enhancements occur through size enlargement, geographical diversification as well as through $\mathrm{X}$ income efficiency of the acquiring firm. The need for size enlargement reflects that the acquiring firm has reached a certain limit in its home market because this market is becoming too small or not sufficiently profitable or the regulating authority opposes further concentration (Abraham/van Dijke 2002), as often observed in Western European countries. Revenue synergies also include strategic considerations such as the protection of future growth potentials, entry into new markets, purchase of strategic resources, protection of current market position as well as the accomplishment of critical corporate size (Holland et al. 2000). Moreover, the international expansion of utility firms also affects the strategic behavior of their suppliers: Domestic suppliers have to ensure that transplanted buyers do not start a relationship with alternative foreign suppliers, because these new relationships could later threaten current suppliers in their own domestic market. Consequently, they also expand abroad (Martin et al. 1998).

Management synergies are a further possible motivation, where the superior management skills of the buying firm can be applied to the takeover target (Jensen 1993). Management synergies are closely linked to operational (X-cost) efficiency, which suggests that the acquiring utility company is more efficient than the target company concerning client relationships and internal processes. Hence, foreign firms enhance target firms' efficiency by streamlining their business operations and bringing access to cheaper resources. Benefits also arise from the acquirer's superior capability of using strategic advantages such as government regulations, markets for corporate control, technology, and tax structures (Kiymaz/Mukherjee 2000). As a result, an increase in value for the firms' shareholders occurs (Leibenstein 1966; Haynes/Thompson 1999). A number of studies of energy utilities in the US contain indications that the 
efficiency of energy utilities could indeed be increased as a result of takeovers (Bacon 1997; Burns et al. 1998).

Another explanation suggests that mergers between energy utilities are driven by the intention of increasing market power and making collusive behavior easier (Kim/Singal 1993; Mulherin/Boone 2000; Tombak 2002). However, the overall evidence for collusion effects following M\&A announcements is rather mixed. For mergers in the airline industry, Kim/Singal (1993) and Singal (1996) present consistent market reactions. Stillman (1983), Eckbo (1983) and Eckbo/Wier (1985) also report findings in favor of expected collusive behavior, while the more recent results of Fee/Thomas (2004) and Sharur (2005) are inconsistent with this view. Despite these mixed results, the collusion argument seems a plausible motive for energy utilities as most national energy markets are dominated by a few main suppliers. In various European markets like France, Germany, Ireland and Greece, the largest suppliers account for over 60 per cent (European Commission 2004). At present, only limited empirical evidence is available that directly shows the attainment of market power through mergers and acquisitions among energy utilities. As Freytag/Schiereck (2009) document for Germany and the US, the market power of a merged firm enlarges when the effect of the M\&A deal reduces market competition. This result implies the capability of forcing higher product and service price levels and hence increasing profits and, consequently, shareholder value (Trautwein 1990). However, an increase in oligopolistic concentration is a clear result of national acquisitions. Cross-border M\&A transactions tend to show more potential for efficiency motives.

Governments of former communist countries in particular often seek foreign acquirers to attract technological and management skills. It has indeed been argued that by bringing in a package of machinery, equipment, technology, management and marketing techniques and expertise in an integral manner, foreign direct investment of any form catalyzes a number of transformation processes and augments national competitive advantages (Czinkota 1991; Ozawa 1992; Estrin et al. 2009).

Despite all technology and know-how transfers of the foreign parent company after privatization involving an international investor, energy enterprises in CEE countries were in general only modestly profitable in the early days of the restructuring process (Rojec 2001). In Hungary, where the share of foreign affiliates in the electricity, gas, steam and water supply already accounted for $28 \%$ in terms of paid-in capital and even $52 \%$ in terms of net sales revenue in 1999 , cross-border M\&As resulted in firm-level restructuring and modernization as well as the integration of Hungarian assets in international networks (Szanyi 2001). Furthermore, there is evidence of technical efficiency gains through economies of scale in European electricity distribution utilities (Growitsch et al. 
2005). Besides, the entrance of foreign players in these industries also entails the transfer of reputation and new brands (Fahy et al. 2003).

As an important precondition and following the integration within the European Union (EU), changes of external factors affected the willingness of Western utility firms to engage in cross-border M\&A transactions. Many new member countries of the EU have undergone significant liberalization in the recent past in order to attract foreign investment. They removed restrictions on foreign direct investment (FDI) and provided high standards of treatment, legal protection and guarantees. Deregulation and privatization programs in various markets resulted in cross-border deals by increasing the availability of domestic companies for sale as well as introducing changes in capital markets with a view toward higher worldwide integration (UNCTAD World Investment Report 2000). Promising economic conditions in the target countries, such as the potential of economic growth or favorable tax and exchange rates, influence cross-border M\&A transactions. Countries with greater potential for economic growth and relatively low tax rates on corporate earnings were more likely to attract FDI. Moreover, countries where the local currency was expected to strengthen against the home currency of the acquirer may attract FDI (Madura 2006).

Event studies examine stock price reactions at the time of the merger announcement as a measure of the outcome. In efficient capital markets, the change of the stock price reflects all expected changes of future cash flows. Overall, the existing evidence provides strong support that the shareholders of target companies benefit upon the announcement of a merger (value increase of $4.9 \%$ to $9.9 \%$ ). These results for utility takeovers are in line with the findings of event studies of acquisitions in general (Andrade et al. 2001). Overall, event study methodology has been extensively used to analyze the effect of all kinds of M\&As on the value for both the acquiring and the target firm. Two findings have more or less consistently emerged: market reactions are on average significantly positive for shareholders of the acquired company and tend to be negative for the shareholders of the bidder.

Despite the large number of studies examining cross-border transactions, most of them concentrate on the acquirer side, or have a geographic focus. The effect of foreign expansions on the stock market valuation of acquiring US multinational firms, for instance, has been widely explored. Some studies report small positive cumulative abnormal returns (CARs) for the US acquirers of foreign targets (Fatemi 1984; Morck/Yeung 1992; Manzon et al. 1994; Markides/Ittner 1994; Lang/Ofek 1995; Yook/McCabe 1996; Markides/Oyon 1998).

Other research finds no evidence that cross-border acquisitions generally create any value for the acquirer (Doukas/Travlos 1988; Datta/Puia 1995; Cakici et al. 1996; Eckbo/Thorburn 2000; Moeller/Schlingemann 2002). Aggarwall/Harper 
(2002) document significant positive wealth effects for acquiring electric utility owners in cross-border M\&As following the deregulation of the US industry in 1992. The evidence of the value effect for non-US acquirers is also mixed. Corhay/Rad (2000) find only weak evidence that international transactions are generally wealth creating for Dutch acquirers involved in cross-border acquisitions. However, Patev et al. (2003) show that the acquirers of CEE banks in privatizations between 1999 and 2001 achieved positive capital market reactions.

Research on the value effect of cross-border transactions on the target firm level has again focused on US companies. Highly significant positive abnormal returns have been reported for different industries and time windows (Conn/Connell 1990; Kang 1993; Hudgins/Seifert 1996; Eun et al. 1996; Brealey et al. 1998; Seth et al. 2000). The positive effect generally even exceeds that of domestic M\&As (Harris/Ravenscraft 1991). This evidence is confirmed by Campa/ Hernando (2004) for acquisitions within the EU-15. However, target firms from regulated industries such as energy, primary industries and financial institutions display a lower return than those in other industries.

Studying the value effect of the privatization of Polish banks between 1996 and 2002, Bohl et al. (2006) show that cross-border acquisitions of previously stateowned Polish banks created significant wealth for the whole Polish banking sector. Cross-border M\&As, both in a privatization or any other transaction, can play a positive role in improving productivity, not only of acquired firms but also in promoting economic restructuring of the host economies (Chen/Findlay 2003). Privatization involving international investors can provide an impetus for $\mathrm{R} \& \mathrm{D}$, thus promoting economic competitiveness and environmental advancement. Meggison/Netter (2001:48) summarize that privatized firms "almost always become more efficient, more profitable, increase their capital investment spending, and become financially healthier", which in turn increases the revenue from taxes for the host country (Loungani/Razin 2001). There is also evidence that foreign ownership of former state-owned enterprises (SOEs) in the CEE region can lead to a rise in exports, which consequently helps to keep a country on "an export-led growth path" (Mihályi 2001). In markets where various potential acquirers bid for inefficiently managed targets, the synergy potential is to a large extent paid as a premium to the shareholders of the target company.

\section{Research questions}

As summarized before, targets of both domestic as well as cross-border M\&As experience positive abnormal returns upon the announcement of the transaction. This is in particular true when there is a competitive bidding process. Moreover, targets should benefit from know-how transfer and increased efficiencies (Simpson et al. 2005). Local targets should also benefit from foreign ownership 
by the access to capital. In a transition country, the cost of capital is usually higher while the availability of capital is lower than in Western economies (Chari et al. 2004).

Hypothesis 1: The announcement of a cross-border acquisition will have a positive impact on the share price of the CEE target.

In the context of cross-border M\&As, relatedness can be expressed by the merger direction being horizontal, vertical or conglomerate with decreasing intensity of relatedness. Horizontal expansions are expected to be most successful simply because they involve projects in the acquiring firm's industry and offer the whole range of synergy realization.

Hypothesis 2: Industry relatedness positively influences the value effect of crossborder M\&As.

A government may for several reasons wish to retain partial ownership of the target in a privatization. Two theories on shared ownership prevail in economic literature: "agency" and "strife" (Pennings et al. 1994). Demsetz/Lehn (1985:1156) explain that according to the "agency" view: "In a very diffusely owned firm, the divergence between benefits and costs would be much larger for the typical owner, and he can be expected to respond by neglecting some tasks of ownership." Thus, an acquirer should have more incentives to monitor and support their investment the higher their stake in the firm is. The "strife" view, however, suggests that - resulting from a transaction costs derivation companies with ownership divided between two approximately equally strong owners may lack sufficient mechanisms to resolve unforeseen dissension (Kogut 1988). Therefore, if a government retains a majority share, it may have conflicting views of decisions made by the value-maximizing private investor.

Moreover, in transition economies, the diffusion of knowledge is of particular concern to international investors because the less developed institutional framework may not fully provide for the efficient protection of intellectual property rights (Meyer 2001). Therefore, the acquirer will only be willing to transfer technology, management skills and other knowledge to the target which would increase efficiency and productivity and, consequently, the value of the firm when majority control is achieved. Consistently Desai et al. (2004) show that partially-owned affiliates of US multinational companies use older technologies and export less to their parents than their wholly-owned equivalents. Furthermore, McDonald (1993) summarizes shared ownership problems for privatized firms in Poland and concludes that dominant ownership by a Western acquirer is critical for technology transfer and post-privatization performance.

Hypothesis 3: The acquisition of a majority ownership in a cross-border transaction is positively related to the value created for the target. 
Markides/Ittner (1994) argue that experienced acquirers that have already been involved in some international acquisitions may be better able to deal with government agencies and to overcome cultural differences. They have superior abilities to evaluate organizational fit and to integrate a former SOE into the acquirer's organization. To what extent these abilities also generate value for the target's shareholders is still rather unexplored. Darkow et al. (2008), for instance, report significant positive effects of bidder M\&A experience in the logistics industry only for the bidder's share price while the effect for target shareholders remains insignificant. However, Meyer/Estrin (1997) suggest that Western companies with both international and regional expertise are more likely to be involved in privatizations in CEE countries. Since CEE countries are unique in their economic situation, bidder experience may have a positive impact on the target firm's post-merger performance.

Hypothesis 4: Experienced acquirers of CEE targets have a more positive impact on the targets' market valuation than first-time bidders.

While Kocenda/Svejnar (2002) show that the higher the proportion of private ownership is, the greater is the possibility of increased performance, Boardman/Laurin (2000) document a positive relationship between retained government ownership of privatized firms and the company performance. This positive effect is explained by insider information because the government might have superior knowledge about the firms' long-run performance and retain larger stakes in better firms. This is consistent with the "signaling effect" of the government's willingness to share residual risk (Perotti 1995). Given the common EU deregulation rules for the internal electricity markets and the ongoing liberalization of energy supply in the individual European Union member states, the electricity wholesale markets are today widely deregulated. Therefore, we expect a positive correlation between divested state-owned stake and share price performance in CEE economies. There are, however, potential negative consequences from public officials, who in their capacity as owner representatives may (often legitimately) also pursue goals - such as preserving employment or maintaining domestic management - that may be at odds with the value maximization of a firm.

Hypothesis 5: The larger the transferring ownership stakes from the government to a private acquirer are, the larger is the value creation for the target shareholders.

\section{Sample selection, data sources and methodology}

The Thompson Financial Securities Data Company's (SDC) Platinum mergers and acquisitions database was used to identify cross-border transactions with a target in CEE countries. The sample includes all mergers and acquisitions between 1995 (the year when privatization of electricity and gas first occurred in 
the CEE area) and 2005. We apply event study methodology, which requires share price data that is unavailable for privately held firms. Therefore, only target firms listed on the stock exchange are included in the sample. Each of the 37 M\&A transactions in the sample satisfy the following selection criteria:

- The target was listed in the Czech Republic, Hungary, Poland or the Slovak Republic for at least 120 trading days prior and 20 trading days after the event.

- The M\&A announcement took place between 1995 and 2005.

- Information on the total return to shareholders of the target firms is available on the Datastream system.

- The target is classified in one of the following SIC code classifications: 1311 (crude petroleum and natural gas), 4911 (electric services), 4931 (electric and other services), 4922 (natural gas transmission), 4924 (natural gas distribution) or 499A (cogeneration, alternative energy sources).

- The transaction is completed.

The acquisitions where a transaction value was recorded amounted to \$ 129 million on average. The average share acquired was $21 \%$, which led to the acquirers on average owning $40 \%$ of the target firms' share capital after the transaction.

We apply event study methodology on firms from CEE countries and use an estimation period of 120 trading days prior to the event window, as suggested by MacKinlay (1997). The announcement date reported in the SDC Platinum database is validated by comparing it to the announcement date reported in the merger market database or the financial press. To estimate the model parameters, we use a standard OLS regression model with the domestic stock market indices as market benchmarks. In accordance with Bohl et al. (2006), who report thin trading in the Polish stock market, betas are estimated applying the Dimson (1979) technique, which involves a multiple regression model. The best results were achieved with two lagged and one lead term and the resulting parameters are used for the following analysis. The abnormal return for each security (ARit) for a given period is then calculated as the difference between the observed return (Rit) for that period and the expected return predicted by the model (E(Rit)):

$$
A R_{i t}=R_{i t}-E\left(R_{i t}\right)
$$

The cumulative abnormal returns (CARs) for the different event windows [t1;t2] of each security $i$ are calculated with the following formula:

$$
C A R_{i t}=\sum_{t=t_{i}}^{t_{2}} A R_{i t}
$$

These CARs are averaged across the whole sample to obtain $\overline{C A R_{t}}$ for each event window. The significance of the CARs of the sample portfolio is tested 
using a general W-test and the test statistic suggested by Boehmer/Musumeci/Poulsen (1991) to adjust for event-induced variance. Having estimated the CAR of the target companies' stocks upon the announcement of a foreign bid, we use multivariate regression analysis to identify factors affecting the value generation. The following dummy variables were tested:

Factor 1: Industry relatedness

Industry relatedness is expressed with the SIC code classification of target and acquirer. The parties are classified to be related and the dummy variable for this proxy set to 1 if they show the same SIC code at either a three or four digit level.

Factor 2: Majority control

Depending on the privatization process, it is often the case that initial minority shares are acquired in order to be allowed to increase the shareholding at a later point in time. The dummy variable indicating the intention of an investor to acquire majority control over the target is defined as the first acquisition the bidder executed at the target firm. That is to say in subsequent transactions this intention would already have been incorporated in the target's stock price. Therefore, the proxy is set to 1 if the acquisition was the first involvement of the bidder at the target.

Factor 3: Frequent/ experienced acquirer

A dummy variable is defined as 1 if the acquirer has already acquired at least another 5\% stake in a CEE energy company.

Factor 4: Privatization as compared to transfer between private investors

A dummy variable is set to 1 if the seller is a government agency.

\section{Results and discussion}

The average market reaction of target stocks on the announcement of takeovers is positive but remarkably low. The [0;5] event window only reports a preliminary significant CAAR of $1.58 \%$. The European non-CEE acquirers pay a very low scaled premium for majority stake acquisitions in utilities of former communist countries. This observation is overall in line with the findings of Bohl et al. (2006) for acquisitions in the Polish banking sector and additional case study evidence by Mußhoff/Schiereck (2007). The common deal structure of the CEE partial privatization trade sales does not oblige the acquirer to give a mandatory acquisition offer for the remaining outstanding shares. In anticipation of this forgoing, there is no reason to expect a significant premium payment to the rest of the shareholders.

However, on average, cross-border M\&As create short-term positive shareholder value for target firms. Hypothesis 1 is supported, and this outcome 
is consistent with the proposition that international acquisitions are associated with net benefits and those targets gain from takeovers. However, the results differ in two ways from the expected values. With a CAAR of $2.43 \%$ for the 40 days surrounding the announcement, the magnitude of the value effect is not only smaller than those reported in other studies for Western countries. What is more, the positive effect does not persist for the entire 61-day event window. Table 1 illustrates the noteworthy effect whereby announcements of crossborder acquisitions trigger a CAAR of up to $2.76 \%$, which then declines for the longest event window. However, these findings are consistent with evidence of cit_bfLowinski et al. (2004),cit_af ref_bf(Lowinski, 2004 ref_num1097)ref_af who also report that an initial highly significant positive value effect in a short time period around the announcement date diminishes when the observation period is extended. This effect might be induced by some availability heuristics. Stocks with prominent news gain additional visibility from less sophisticated investors who trade on this news and generate short-term returns which do not continue over longer horizons (Huberman 2001; Grinblatt/Kelohraju 2001; Zhu 2002). Lastly, we interpret our results in a way that hypothesis 1 is in fact not supported.

Table 1. CAAR for energy targets during the announcement window

The table presents the arerage (CAAR) and the median of the cumulated abnormal returns of 32 stock quoted firms, between 1995 and 2005 for cross border transactions between Germany, Hungary, the Czech Republic and the Slowak Republic. "Positive" denotes the percentage of positive abnomal retums of the analyzed sample.

\pm \# describe the statistical significance of the significance lewels of $90 \%, 95 \%$ and $99 \%$ for the mean test suggested by Boehmer el al. (2001) and the Wiconon Test for medians. The underlying estimation model refers to the market model.

\begin{tabular}{|c|c|c|c|c|c|c|c|c|c|c|}
\hline $\begin{array}{l}\text { Event } \\
\text { Window }\end{array}$ & CAAR & Std Dev & z-value & Hedlian & Vilue & |lin & Wax & Num. & Neg. & Positive \\
\hline$-30 ; 30]$ & $-0,10 \%$ & $43 \%$ & $\sqrt{11}$ & $0,02 \%$ & 684 & $6099 \%$ & $\overline{\%}$ & $\overline{61}$ & 31 & 6549 \\
\hline$[20 ; 20]$ & $2,43 \%$ & $19,51 \%$ & 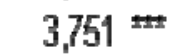 & $2,23 \%$ & $=$ & $-36,90 \%$ & $5,22 \%$ & d4 & 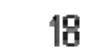 & $558 \%$ \\
\hline$[-15 ; 15]$ & $2,76 \%$ & 18,13 & $4,139=$ & $1,60 \%$ & $m$ & $-31,91 \%$ & 60 $97 \%$ & & 12 & $19 \%$ \\
\hline$[-10 ; 10]$ & $0,37 \%$ & $15,60 \%$ & 0,213 & 0,82 & 3,84 & $-36,83 \%$ & $42, i$ & & 0 & $798 \%$ \\
\hline$[-5 ; 5]$ & $2,23 \%$ & $16,06 \%$ & $3,021=$ & $0,00 \%$ & $2,223=$ & $35,50 \%$ & $5 b, 5 / \%$ & 11 & 3 & $41,477 \%$ \\
\hline$[-1: 1]$ & $0,43 \%$ & 7 & 0, & $0,00 \%$ & 1,0 & $-14,94 \%$ & 23,3 & 3 & I & $43,750 \%$ \\
\hline$[-1 ; 0]$ & $0,15 \%$ & $4,00 \%$ & 0,23 & $0,00 \%$ & 1,34 & $99 \%$ & 9 & 2 & 1 & $43,750 \%$ \\
\hline$[0: 1]$ & $0,09 \%$ & $\%$ & 0,84 & $\%$ & 0,4 & $-9,94 \%$ & $18,35 \%$ & 2 & 1 &, $625 \%$ \\
\hline$[0: 5]$ & $1,58 \%$ & $\%$ & & $3 \%$ & 1,57 & $-29,95 \%$ & $31,78 \%$ & 6 & 1 & $188 \%$ \\
\hline$[0: 10]$ & $-0,77 \%$ & 11 & & $0,81 \%$ & no & $-27,42 \%$ & $20,81 \%$ & 11 & ) & $73 \%$ \\
\hline $0: 1$ & $0,61 \%$ & $1151 \%$ & 1,90 & $0,52 \%$ & 0414 & $.27 .42 \%$ & $3099 \%$ & 6 & 7 & $820 \%$ \\
\hline $0: 2$ & $0,32 \%$ & 12 & 1,5 & & 1,6 & $.31,02 \%$ & 29 & 21 & 10 & $81 \%$ \\
\hline ; 30] & $-289 \%$ & $14,50 \%$ & $3,415=$ & $-322 \%$ & 0,294 & $.2533 \%$ & $2685 \%$ & 31 & 18 & $36391 \%$ \\
\hline
\end{tabular}


Table 2. CAAR for energy acquirers during the announcement window

The table presents the arerage (CAAR) and the median of the cumulated abnomal returns of 21 stock quoted fims, between 1995 and 2005 for cross bonder transactions between Gemany, Hungary, the Czech Republic and the Slowak Republic. "Positwe" denotes the percentage of positive abnomal retums of the analyzed sample.

*, describe the statistical significance of the significance leyels of $90 \%$, $95 \%$ and $99 \%$ for the mean test suggested by 8oehrier el al. (2001) and the Wiconon Test for medians. The underlying estimation model refers to the market model.

\begin{tabular}{|c|c|c|c|c|c|c|c|c|c|c|}
\hline $\begin{array}{l}\text { Event } \\
\text { Wintow }\end{array}$ & CAAR & d Dev & z-vallue & Hellian & Vallue & lin & Hax & Num. & Ney. & Posi \\
\hline$[30 ; 30]$ & $-3,00 \%$ & $11,070 \%$ & 6,906 & $-2,96 \%$ & $6,597=$ & $-2306 \%$ & $21,39 \%$ & ס & $\overline{29}$ & $\overline{4}$ \\
\hline$[20 ; 20]$ & $-1,52 \%$ & $10,80 \%$ & 2,442 & $-2,70 \%$ & 3,000 & $-17,81 \%$ & $95 \%$ & & w & $257 \%$ \\
\hline$[-15 ; 15]$ & $0,76 \%$ & $6.23 \%$ & 6,560 & $0,00 \%$ & $2,665=$ & $-15,44 \%$ & $12,24 \%$ & 31 & 15 & $39,705 \%$ \\
\hline$[10: 10]$ & $0,52 \%$ & $5,50 \%$ & 0,184 & $-0,30 \%$ & 0,052 & $-12,26 \%$ & $12,87 \%$ & 21 & 10 & $136 \%$ \\
\hline$[5: 5]$ & $1,49 \%$ & $5,39 \%$ & 4,374 & $1,94 \%$ & $2,845 \#$ & $-9,98 \%$ & $11,26 \%$ & 11 & 4 & $39,394 \%$ \\
\hline$[-1: 1]$ & $0,50 \%$ & $2,45 \%$ & 5,734 & $0,37 \%$ & 1,604 & $6,29 \%$ & $4,14 \%$ & 3 & ] & $1857 \%$ \\
\hline$[-1: 0]$ & $0,41 \%$ & $1,89 \%$ & 6,353 & $0,00 \%$ & 1,342 & $.376 \%$ & $5,30 \%$ & 2 & 0 & $40,476 \%$ \\
\hline$[0: 1]$ & $0,42 \%$ & $2,30 \%$ & $2,599 \pm$ & $0,34 \%$ & $.1,342$ & $6,29 \%$ & $5,19 \%$ & 2 & 0 & $45,238 \%$ \\
\hline$[0: 5]$ & $0,60 \%$ & $4,43 \%$ & 0,728 & $0,00 \%$ & $2,201=$ & $-8,72 \%$ & $9,12 \%$ & 6 & 3 & $42,063 \%$ \\
\hline$[0: 10]$ & $0,35 \%$ & $5,50 \%$ & 1,094 & $0,00 \%$ & 1,600 & $-14,73 \%$ & $7,66 \%$ & 11 & 5 & $43,723 \%$ \\
\hline$[0 ; 15]$ & $0,32 \%$ & $5,57 \%$ & 0,376 & $0,30 \%$ & 1,241 & $.12,40 \%$ & $11,57 \%$ & 16 & 0 & $43,452 \%$ \\
\hline$[0 ; 20]$ & $-1,24 \%$ & $9,13 \%$ & 2,322 & $-0,24 \%$ & 1,269 & $.15,37 \%$ & $18,65 \%$ & 21 & 9 & $43,084 \%$ \\
\hline$[0: 30]$ & $-1,63 \%$ & $7,97 \%$ & 6,509 & $0,82 \%$ & 1,470 & $-16,45 \%$ & $12,75 \%$ & 31 & 13 & $43525 \%$ \\
\hline
\end{tabular}

In line with most prior research (Loughran/Vijh 1997cit_af ref_bf(Loughran, 1997 ref_num1095)ref_af), shareholders of acquiring firms lose significantly, at least for event windows longer than 15 days. This finding is confirmed by the results of the few combined entity returns of targets and bidders (not reported here). The overall capital market reaction of the announced M\&A transactions in the utility sectors of CEE economies is negative. We interpret this observation, in line with Kavanagh (2002), that the upgrading process of the CEE energy plants and infrastructure to EU standards and the implementation of ecological improvements take time and instant profits are unlikely. The uncertainty of acquisition success and the lack of long-term experience with the performance of large-scale energy enterprise privatizations in CEE countries can explain investors' skepticism and the negative revaluation of acquirers' shares. However, as there is a lot of variance in this aggregate result, further analyses of returndriving factors will follow. 
To provide further explanations on the target stock performance surrounding the M\&A announcement, we take the event window [-15;15] abnormal return as the dependent variable for regression analyses. We selected this window because it describes a fairly well specified timeperiod to explain M\&A announcement effects. Alternatively tested windows show qualitatively very similar results to the findings reported here. The regression analysis applying a WLS approach will estimate the following regression to address our hypotheses 2 to 5:

CAR (MSCIc) $[-15 ; 15]=\mathrm{ai}+\mathrm{b} 1 *$ Hungary $+\mathrm{b} 2 *$ Poland $+\mathrm{b} 3 *$ Slovak Republic $+\mathrm{b} 4 *$ Time $+\mathrm{b} 5 *$ Horizontal merger $+\mathrm{b} 6 *$ Acquisition of Control + $\mathrm{b} 7 *$ Experience $+\mathrm{b} 8 *$ Privatization

Table 3. Key drivers of $M \& A$ success [multivariate regression analyses [-15;15]]

This table summarizes the results of a weighted least square regression analysis of cumulated abnormal retums as the dependent variable. The values in brackets describe the $p$ yalue corresponding to the accordant $t$ statısuc. $"=$, describe the statisucal significance of the s gniftcance levels of $90 \%$, 95\% and $99 \%$. The dummles described by the left sided characters take the value of one, if thelp case steps in for the corresponding firm.

\begin{tabular}{|c|c|c|c|c|c|c|}
\hline \multirow{2}{*}{$\begin{array}{l}\text { Dependent } \\
\text { Model }\end{array}$} & \multicolumn{2}{|c|}{ CAARAcquirer } & \multicolumn{2}{|c|}{ CAAR Target } & \multicolumn{2}{|c|}{ CAAR Entity } \\
\hline & 1 & 2 & 3 & 4 & 5 & B \\
\hline \multirow[t]{2}{*}{$\overline{\text { Constant }}$} & $-0,12915$ & $-0,08701$ & 0,39620 & $0,20630=$ & 0,12368 & 0,01912 \\
\hline & $(0,2181)$ & $(0,1780)$ & $\left(0,10^{1} 1\right)$ & $(0,2602)$ & $(0,5427)$ & $(0,8773)$ \\
\hline \multirow[t]{2}{*}{ Hungary } & 0,06440 & & $-0,04 E 55$ & & $-0,10075$ & \\
\hline & $(0,4043)$ & & $(0,7882)$ & & $(0,5090)$ & \\
\hline \multirow[t]{2}{*}{ Poląnd } & $-0,00760$ & & $-0,00995$ & & 0,01556 & \\
\hline & $(0,9332)$ & & $(0,9633)$ & & $.0,9312)$ & \\
\hline \multirow{2}{*}{ Slowak Republic } & 0,04104 & & $-0,28184$ & & $-0,13366$ & \\
\hline & $(0,7081)$ & & $\left(0,23^{4} 5\right)$ & & $0,541,3)$ & \\
\hline \multirow[t]{2}{*}{ Time } & $-0,01404$ & $-0,04409$ & $=0,04490$ & $0,[1927 *$ & $=0,02533$ & 0,02944 \\
\hline & $(0,8972)$ & $(0,1691)$ & $(0,7747)$ & $(0,9602)$ & $0,8246)$ & $(0,6322)$ \\
\hline \multirow[t]{2}{*}{ Horizontal merger } & 0,04192 & 0,02678 & $-0,33[74=$ & $-0,17864=$ & $-0,11360$ & $-0,05774$ \\
\hline & $(0,5646)$ & $(0,5901)$ & $(0,0409)$ & $(0,2774)$ & $0,4348)$ & $(0, \% 68)$ \\
\hline \multirow[t]{2}{*}{ Majurity of cuntrul } & 0,06027 & 0,05992 & $-0,07802$ & $-0, C 7091$ & $-0,04201$ & $-0,03782$ \\
\hline & $(0,1380)$ & $(0,1001)$ & $(0,3364)$ & $(0,3254)$ & $.0,5073)$ & $(0,5929)$ \\
\hline \multirow[t]{2}{*}{ Experience } & 0,02912 & 0,04463 & 0,04106 & $0,[3149$ & $-0,02068$ & $-0,0 \$ 209$ \\
\hline & $(0,4674)$ & $(0,1899)$ & $(0,6194)$ & $(0, \hat{6} 677)$ & $(0,7930)$ & $(0,5220)$ \\
\hline \multirow[t]{2}{*}{ Privatization } & $-\pi, \Pi 281 \Pi$ & $-0,0405 \mathrm{~A}$ & ก,กnรก1 & $=n, \mathbf{n} 19.39$ & $n, 0 n 384$ & n,ח1614 \\
\hline & $(0,4749)$ & $(0,1638)$ & $(0,9997)$ & $(0,7763)$ & $0,9603)$ & $(0,7721)$ \\
\hline$\overline{R^{2}}$ & $67,50 \%$ & $40,20 \%$ & $19,70 \%$ & $36,50 \%$ & $17,10 \%$ & $10,00 \%$ \\
\hline$R^{2}$ adj. & $45,56 \%$ & $20,30 \%$ & $-8,20 \%$ & $13,30 \%$ & $-38,20 \%$ & $-20,00 \%$ \\
\hline Durbin Watson & 2,392 & 2,274 & 1,671 & 1,943 & 2,302 & 2,272 \\
\hline F- Statisțic & 1,255 & 2,018 & 0,705 & 0,797 & 0,309 & 0,334 \\
\hline $\mathbb{N}$ & 24 & 24 & 34 & 34 & 34 & 34 \\
\hline
\end{tabular}


'Horizontal merger' is in this case the benchmark transaction. A negative sign can be interpreted in a way that acquisitions from non-related industrial bidders are worse than horizontal deals. To check for time varying effects as well as for country-specific peculiarities, we use a time dummy for transactions before and after the year 2000 and three country dummies (taking the Czech transactions as a benchmark). Table 3 summarizes the main findings.

While the overall explanatory power is not particularly large, the results nevertheless indicate the importance of industry relatedness for M\&As in the CEE energy industry. Industry relatedness in the form of horizontal acquisitions results in more positive market reactions compared to vertical or diversifying transactions. Hypothesis 2 is thus supported. Industry relatedness in our context is usually an indicator for an acquirer in the form of a large Western utility provider which is generally perceived to have high competencies in managing smaller acquisitions and in using bargaining power and political networks to enforce top management decisions. The insignificant coefficient can be interpreted in the context of the technology the new owners have to invest in. It was argued that in transition economies the diffusion of knowledge is of particular concern to international investors because the less developed institutional framework may not fully provide for the efficient protection of intellectual property rights (Meyer 2001). Therefore, acquirers may only be willing to transfer technology, management skills and other knowledge to the target which would increase efficiency and productivity and, consequently, the value of the firm when majority control is achieved. However, when capital markets do not specifically award an acquisition of majority control, then the applied technology cannot be considered too sensitive. Indeed, utility technology is rather well known for CEE countries. It is not critical to import as foreign direct investment and it is not self developed by the operators of the power stations.

Hypothesis 4 argued that more experienced bidders have a more positive impact on the target's market valuation. However, within this M\&A sample of large Western utilities, the divergences in acquisition experience are overall not so extreme. The (partial) sellers in the transactions under consideration will usually follow strategic interests in the form of generating technological upgrading and realizing efficiency gains - based on technologies which are not so sensitive, as was argued for hypothesis 3. These strategic aims are not extraordinarily challenging and they will commonly harmonize with the interests of all shareholder parties. Therefore, the insignificance of the experience coefficient is consistent to the parameter value of the majority coefficient. Acquisition experience and the specific shareholder composition are of minor importance.

Hypothesis 5 claims that the larger the transferring ownership stakes from the government to a private acquirer are, the larger is the value creation for the target shareholders. This hypothesis is only tested indirectly. Both the dummy 
variable for the majority size of the acquired stake and the dummy variable for the privatization transaction show insignificant coefficients. The specification is driven by the information in our data source, and the finding is not surprising given the previously discussed results for the coefficients. Privatizations per se are not value generating for the companies in our sample, which are already partly privatized via IPOs.

We interpret our findings in line with these assumed perceptions. Consequently, neither majority stake acquisitions nor bidder experience or remaining stakes of the privatizing state significantly influence the wealth effects of target shareholders in cross-border acquisitions in the CEE energy sectors. The three hypotheses 3 to 5 are not supported by our results.

\section{Conclusion}

This study on the CEE energy market reports significant short-term positive results for cross-border M\&A transactions that show the same tendency as the evidence provided by cit_bfUhlenbruck/De Castro (2000), who illustrate that foreign ownership has a significant wealth gain for target companies. The energy target companies in the Czech Republic, Hungary, Poland and Slovak Republic show a significantly positive average abnormal stock return of up to $2.23 \%$ during the announcement window $[-5 ;+5]$ in the period from 1995 to 2005. The same significantly positive effect could be observed for acquirers from Western countries. Here abnormal stock returns reach a level of $1.49 \%$ during the same event window.

Given frequently expressed concerns about stock market efficiency in CEE countries and the comparably high risk associated with cross-border acquisitions, we interpret these findings with some caution. Over longer time horizons and event windows of up to 61 days the performance of target stocks proves to be significantly negative. Therefore, we cannot exclude that positive share price performance around the announcement date was only driven by some psychological factors like availability biases. M\&As in the energy sectors under consideration seem to be of limited short-term attractiveness for target shareholders. Further research should first of all try to confirm these results by including recent evidence. Secondly, an extension of the event period of up to three years and an inclusion of accounting information can provide additional insights on the sustainability of the short-term success. The exploration of this additional accounting data source with operational profits over time also makes it possible to test whether the event study methodology, which iswell established in Western capital markets, is also appropriate for studies in CEE countries. As one implicit critical assumption here is information efficiency, there are still some doubts which must be addressed. 
Multivariate regression analyses detect only one factor contributing significantly to shareholder value, namely the industrial relatedness between bidder and target. Horizontal mergers performed better than vertical and diversifying transactions. Neither the size of the acquired stake nor partial government ownership have any (negative) impact. Additionally, the (partial) state or private sellers in the horizontal transactions under consideration will usually follow strategic interests in the form of generating technological upgrading and realizing efficiency gains. These strategic aims will commonly harmonize with the interests of the new shareholders. Therefore, the specific shareholder composition after the M\&A transactions is of minor importance. Once again, this evidence is derived from a limited data sample, which should be extended in future research projects.

From a foreign investor's point of view, our findings signal that betting on potential privatization targets is not a short-term value-promising strategy. This result is not specific for CEE countries as many private investors, for example, lost money during the second and third stage of the privatization of the Deutsche Telekom AG in Germany. This cautious interpretation of the evidence documented above also does not imply any specific need for action for policy makers are regulation authorities. The capital market reaction to the pricing of the acquisition does not offer a clear signal for misevaluation but can be interpreted in a way that the vendors of the shares realized a value which is considered to be very close to recent prices on the stock exchange.

However, the insignificant results from our regression analyses can indicate that findings are specific to the energy sector, where technology is not as sensitive as in other industries. Therefore, we recommend additional M\&A research on other sectors to reappraise our results.

\section{References}

Abraham, J.P./Dijke, P.V. (2002): European financial cross-border consolidation: At the crossroads in Europe? By exception, Evolution or revolution?, in: SUERF Studies 22, Vienna.

Aggarwal, R./Harper, J.T. (2002): First mover advantage in electric utility foreign acquisitions: Evidence from an extended event study methodology, Working Paper.

Ahnefeld, M.(ed.) (2008): Information signaling and ownership transition - Value effects of share issue privatizations, in: Corporate Ownership and Control, 6, 44-57.

Allen, J.W./Phillips, G.M. (2000): Corporate equity ownership, strategic alliances, and product market relationships, in: The Journal of Finance, 55, 2791-2815.

Asquith, P. (1983): Merger bids, uncertainty, and stockholder returns, in: Journal of Financial Economics 11, 1983, 51-83.

Berger, A.N.(ed.) (2000): Globalization of financial institutions: Evidence from cross-border banking performance, in: Brookings-Wharton Papers on Financial Services, 3, 23-136. 
Berkovitch, E./Narayanan, M.P. (1993): Motives for takeovers: An empirical investigation, in: Journal of Financial and Quantitative Analysis, 28, 347-362.

Boardman, N.E./Laurin, C. (2000): Factors affecting the stock price performance of share issued privatizations, in: Journal of Applied Economics, 32, 1451-1464.

Boehmer, E./Musumeci, J./Poulsen, A.B. (1991): Event-study methodology under conditions of event-induced variance, in: Journal of Financial Economics, 30, 253-272.

Bohl, M.T./Havrylchyk, O./Schiereck, D. (2006): Foreign acquisitions and industry wealth effects of privatisation: Evidence from the Polish banking industry, Balling, M./ Lierman F./Mullineux A. (eds.): Stability and efficiency of financial markets in Central and Eastern Europe, Routledge 2006, 80-95.

Boubakri, N./Cosset, J.C. (1998): Financial and operating performance of newly privatized firms: Evidence from developing countries, in: The Journal of Finance, 53, 1081-1110.

Brealey, R.A./Cooper, I.A./Kaplanis, E. (1998): International sources of risk: Evidence from cross-border mergers. London Business School Working Paper.

Cakici, N./Hessel, C./Tandon, K. (1996): Foreign acquisitions in the United States: Effect on shareholder wealth of foreign acquiring firms, in: Journal of Banking and Finance, 20, 307-329.

Campa, J.M./Hernando, I. (2004): Shareholder value creation in European M\&As, in: European Financial Management, 10, 47-81.

Chari, A./Ouimet, P./Tesar, L.L. (2004): Cross border mergers and acquisitions in emerging markets: The stock market valuation of corporate control, EFA 2004 Maastricht Meetings Paper No. 3479.

Chen, C./Findlay, C. (2003): A Review of Cross-border Mergers and Acquisitions in APEC, in: Asian-Pacific Economic Literature, 17, 14-38.

Clark, J.A. (1988): Economies of scale and scope at depository financial institutions: a review of the literature, in: Economic Review (Federal Reserve Bank of Kansas City), 73, 1633.

Conn, R.L./Connell, F. (1990): International Mergers: Returns to US and British Firms, in: Journal of Business Finance and Accounting, 17, 689-711.

Corhay, A./Rad, A.T. (2000): International acquisitions and shareholder wealth - Evidence from the Netherlands, in: International Review of Financial Analysis, 9, 163-174.

Czinkota, M. (1991): The EC '92 and Eastern Europe: Effects of integrations vs. Disintegration, in: The Columbia Journal of World Business, 26, 20-27.

Datamonitor (2005): Czech Republic/ Hungary/ Poland - Utilities - Industry Profiles, August 2005, London.

Datta, D.K./Puia, G. (1995): Cross-border acquisitions: an examination of the influence of relatedness and cultural fit on shareholder value creation in US acquiring firms, in: Management International Review, 35, 337-359.

Demsetz, H./Lehn, K. (1985): The structure of corporate ownership: Causes and consequences, in: Journal of Political Economy, 93, 1155-1177.

Desai, M.A./Foley, C.F./Hines, J.R. (2004): The costs of shared ownership: Evidence from international joint ventures, in: Journal of Financial Economics, 73, 323-374. 
Dimson, E. (1979): Risk measurement when shares are subject to infrequent trading, in: Journal of Financial Economics, 7, 197-226.

Doukas, J./Travlos, N.G. (1988): The effect of corporate multinationalism on shareholders' wealth: Evidence from international acquisitions, in: The Journal of Finance, 43, 1161-1175.

Eckbo, B.E./Thorburn, K.S. (2000): Gains to bidder firms revisited: Domestic and foreign acquisitions in Canada, in: Journal of Financial and Quantitative Analysis, 35, 1-25.

Energy Information Administration (2003a). Status of natural gas residential choice programs by state as of December 2003. http://www.eia.doe.gov/oil_gas/natural_gas /restructure/ restructure.html.

Energy Information Administration (2003b). Status of state electric industry restructuring activity. http://www.eia.doe.gov/cneaf/electricity/chg_str/regmap.html.

Estrin, S.(ed.) (2009): The effects of privatization and ownership in transition economies, in: Journal of Economic Literature, 47, 699-728.

Eun, C.S./Kolodny, R./Scheraga, C. (1996): Cross-border acquisitions and shareholder wealth: Test of the synergy and internalization hypothesis, in: Journal of Banking and Finance, 20, 1559-1582.

European Commission (2004): Third benchmarking report on the implementation of the internal electricity and gas market. Brussels.

Fahy, J.(ed.) (2003): Privatisation and sustainable competitive advantage in the emerging economies of Central Europe, in: Management International Review, 43, 407-428.

Fatemi, A.M. (1984): Shareholder benefits from corporate international diversification, in: Journal of Finance, 39, 1325-1344.

Fisher, L. (1966): Some new stock-market indexes, in: Journal of Business, 39, Part 2: Supplement on Security Prices, 1191-225.

Freytag, A./Schiereck, D. (2009): Consolidation and market power of energy utilities - The case of US-American and German Utility Takeovers, University of Jena, Working Paper.

Grinblatt, M./Keloharju, M. (2001): How distance, language, and culture influence stockholdings and trades, In: Journal of Finance, 56, 1053-1073.

Growitsch, C./Jamasb, T./Pollitt, M. (2005): Quality of service, efficiency, and scale in network industries: An analysis of European electricity distribution, Halle Institute for Economic Research (IWH) Discussion Paper, No. 3.

Haddad, M./Harrison, A. (1993): Are there positive spillovers from direct foreign investment? - Evidence from panel data from Morocco, in: Journal of Development Economies, 42, $51-74$.

Harris, R.S./Ravenscraft, D. (1991): The role of acquisitions in foreign direct investment: Evidence from the US stock market, in: Journal of Finance, 46, 825-844.

Haynes, M./Thompson, S. (1999): The productivity effects of bank mergers: Evidence from the UK building societies, in: Journal of Banking and Finance, 23, 825-846. 
Holland, D.(ed.) (2000): The determinants and impacts of foreign direct investment in Central and Eastern Europe: A comparison of survey and econometric evidence, in: Transnational Corporations, 9, 163-212.

Huberman, G. (2001): Familiarity breeds investment, in: Review of Financial Studies, 14, 659-680.

Hudgins, S.C./Seifert, B. (1996): Stockholders and international acquisitions of financial firms: An emphasis on banking, in: Journal of Financial Services Research, 10, 163180.

Isser, S.N. (2004): Electricity deregulation: Kilowatts for nothing and your BTUs for free, in: Review of Policy Research 20, 219-238.

Jensen, M.C. (1993): The modern industrial revolution - Exit, and the failure of internal control systems. Journal of Finance 48, 831-880.

Jensen, M.C./Ruback, R.S. (1983): The market for corporate control: the scientific evidence, $11,5-50$.

Joskow, P.L. (1998): Electricity sectors in transition, in: Energy Journal, 19, 25-53.

Kang, J.K. (1993): The international market for corporate control - Merger and acquisitions from US firms by Japanese firms, in: Journal of Financial Economics, 34, 345-371.

Kavanagh, R. (2002): Electric acid test - Germans plug into power privatization, in: NEFTE Compass, May 16, 2002, 5.

Kiesling, L. (2004): The North American blackout and electricity policy: Alternatives to transmission construction, in: Economic Affairs 24, 53-57.

Kiymaz, H./Mukherjee, T.K. (2000): The Impact of Country Diversification on Wealth Effects in Cross-Border Mergers, in: The Financial Review, 35, 37-58.

Kocenda, E./Svejnar, J. (2002): The effects of ownership forms and concentration on firm performance after large-Scale privatization, in: William Davidson Working Paper, No. 471.

Kogut, B. (1988): Joint Ventures: Theoretical and empirical perspectives, in: Strategic Management Journal, 9, 319-332.

Lang, H.P./Ofek, E. (1995): Why do firms invest in Eastern Europe?, in: European Financial Management, 1, 147-171.

Leibenstein, H. (1966): Allocative efficiency vs. 'X-Efficiency', in: American Economic Review, 56, 392-415.

Llewellyn, D.T. (1999): The new economics of banking, in: SUERF Studies, CIP-Gegevens Koninklijke Bibliotheek, Den Haag.

Loungani, P./Razin, A. (2001): How beneficial is foreign direct investment for developing countries, in: Finance and Development, International Monetary Fund, 38, 6-9.

Loughran, T./Vijh, A.M. (1997): Do long-term shareholders benefit from corporate acquisitions?, in: The Journal of Finance, 52, 1765-1790.

Lowinski, F./Schiereck, D./Thomas, T.W. (2004): The effect of (cross border) acquisitions on shareholder wealth - Evidence from Switzerland, in: Review of Quantitative Finance and Accounting, 22, 3, 315-330. 
MacKinlay, A.C. (1997): Event studies in economics and finance, in: Journal of Economic Literature, 35, 1, 13-39.

Madura, J. (2006): International financial management, 8th Ed., Ohio.

Manzon, G.B./Sharp, D.J./Travlos, N.G. (1994): An empirical study of the consequences of US tax rules for international acquisitions by US firms, in: The Journal of Finance, 49, 1893-1904.

Markides, C.C./Ittner, C.D. (1994): Shareholder benefits from corporate international diversification: Evidence from US international acquisitions, in: Journal of International Business Studies, 25, 343-366.

Markides, C.C./Oyon, D. (1998): International Acquisitions: Do they create value for shareholders?, in: European Management Journal, 16, 125-135.

Martin, X./Swarminathan, A./Mitchell, W. (1998): Organizational evolution in the interorganizational environment: Incentives and constraints on international expansion strategy, in: Administrative Science Quarterly, 43, 566-601.

McDonald, K.R. (1993): Why privatization is not enough, in: Harvard Business Review, 71, 49-59.

Megginson, W.L./Netter, J.M. (2001): From state to market: A survey of empirical studies on privatization, in: Journal of Economic Literature, 39, 321-389.

Meyer, K.E. (2001): Institutions, transaction costs, and entry mode choices in Eastern Europe, in: Journal of International Business Studies, 32, 2, 357-367.

Meyer, K.E./Estrin, S. (1997): Privatization acquisition and direct foreign investment: Who buys state-owned enterprises, in: MOCT-MOST Economic Policy in Transitional Economies, 7, 159-172.

Mihályi, P. (2001): The evolution of Hungary's approach to FDI in post-Communist privatization, in: Transnational Corporations, 10, 60-73.

Molyneux, P./Altunbaş, Y./Gardener, E.P.M. (1996): Efficiency in European banking, John Wiley and Sons, Inc., New York, 1996.

Moeller, S.B./Schlingemann, F.P. (2002): Are cross-border acquisitions different from domestic acquisitions? - Evidence on stock and operating performance of US acquirers. University of Pittsburgh Working Paper.

Morck, R./Yeung, B. (1992): Internalization: An event study test, in: Journal of International Economics, 33, 41-56.

Mueller, Dennis C. (1969): A theory of conglomerate mergers, in: Quarterly Journal of Economics, 83, 643-659.

Mußhoff, J./Schiereck, D. (2007): Erfolgreiche Bankakquisitionen in Europa - Das Beispiel UniCredit und Pekao, in: Zeitschrift für Bankrecht und Bankwirtschaft, 19, 464-487.

Ozawa, T. (1992): Foreign direct investment and economic development, in: Transnational Corporations, 1, 27-54.

Patev, P.G./Lyroudi, K./Kanaryan, N.K. (2002): Bank privatisation in Central and Eastern Europe through the view of Western European stock markets, in: Tsenov Academy of Economics Department of Finance and Credit Working Paper, 02, 23. 
Pennings, J.M./Barkema, H./Douma, S. (1994): Organizational learning and diversification, in: Academy of Management Journal, 37, 608-640.

Perotti, E.C. (1995): Credible privatization, in: American Economic Review, 85, 847-859.

Pesic, R.V./Ürge-Vorsatz, B. (2001): Restructuring of the Hungarian electricity industry, in: Post-Communist Economics, 1, 85-99.

Renze-Westendorf, M./Schiereck, D./Zeidler, F. (2009): Cross border acquisitions and shareholder wealth - Evidence from Spain, in: Management Research, 7, 127-140.

Rojec, M. (2001): The restructuring of firms in foreign privatizations in Central and Eastern European countries, in: Transnational Corporations, 10, 1-24.

Roll, R. (1986): The hubris hypothesis of corporate takeovers, in: Journal of Business, 59, 197-216.

Seth, A./Song, K.P./Pettit, R. (2000): Synergy, managerialism or hubris? An empirical examination of motives for foreign acquisitions of US firms, in: Journal of International Business Studies, 31, 387-405.

Simpson, J./Bilousenko, O./Piovesana, V. (2005): Developments in Central and Eastern Europe's energy markets, in: International Financial Law Review, 24, 53-55.

Singh, H./Montgomery, C.A. (1987): Corporate acquisition strategies and economic performance, in: Strategic Management Journal, 8, 377-386.

Szanyi, M. (2001): Privatization and greenfield FDI in the economic restructuring of Hungary, in: Transnational Corporations, 10, 25-37.

Ürge-Vorsatz, D./Paizs, L./Pesic, R.V. (2003): Restructuring, liberalization and EU accession: Are transition economies moving towards more sustainable electricity markets? In: ECEEE 2003 Summer Study - Time to turn down energy demand, http://www.ceu.hu/envsci/research/libero.pdf.

Uhlenbruck, K./de Castro, J.O. (2000): Foreign acquisitions in Central and Eastern Europe: outcomes of privatization in transitional economies, in: The Academy of Management Journal, 43, 3, 381-402.

United Nations Conference on Trade and Development (UNCTAD), World Investment Report 2000: Cross-Border Mergers and Acquisitions and Development. New York/Geneva: United Nations, 2000; www.unctad.org.

Yook, K.C./McCabe, G.M. (1996): The effect of international acquisitions on shareholders' wealth, in: Mid-Atlantic Journal of Business, 32, 5-17.

Zhu, N. (2002): The local bias of individual investors, Yale School of Management Working Paper. 